\title{
Hepatitis G Infection
}

National Cancer Institute

\section{Source}

National Cancer Institute. Hepatitis G Infection. NCI Thesaurus. Code C89782.

A form of liver inflammation caused by the hepatitis $\mathrm{G}$ virus. 